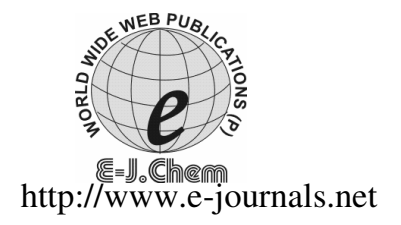

\title{
A Green Solventless Protocol for the Synthesis of $\beta$-Enaminones and $\beta$-Enamino Esters Using Silica Sulfuric Acid as a Highly Efficient, Heterogeneous and Reusable Catalyst
}

\author{
ALIREZA HASANINEJAD*, ABDOLKARIM ZARE", \\ MOHAMMAD REZA MOHAMMADIZADEH, \\ MOHSEN SHEKOUHY and AHMAD REZA MOOSAVI-ZARE ${ }^{\S}$ \\ Department of Chemistry, Faculty of Sciences, \\ Persian Gulf University, Bushehr 75169, Iran. \\ \#Department of Chemistry, Payame Noor University (PNU), Iran. \\ ${ }^{\S}$ Faculty of Chemistry, Bu-Ali Sina University, \\ P. O. Box 4135, Hamedan 6517838683, Iran. \\ ahassaninejad@yahoo.com
}

Received 31 July 2009; Accepted 25 September 2009

\begin{abstract}
Silica sulfuric acid is utilized as a green, highly efficient, heterogeneous and recyclable catalyst for the preparation of $\beta$-enaminones and $\beta$-enamino esters from amines and $\beta$-dicarbonyl compounds under solvent-free conditions at $80^{\circ} \mathrm{C}$. Using this method, the title compounds are produced in high to excellent yields and in short reaction times.
\end{abstract}

Keywords: $\beta$-Enaminone, $\beta$-Enamino ester, Silica sulfuric acid, Solvent-free, Green chemistry.

\section{Introduction}

$\beta$-Enaminones and $\beta$-enamino esters have been extensively used as key intermediates in organic synthesis ${ }^{1-3}$ and the chemistry of these compounds have been reviewed ${ }^{4}$. In particular they have been employed as synthons of a wide variety of bioactive heterocycles s.7 $^{5-\text { as well as }}$ pharmaceutical compounds having anti-epileptic $c^{8,9}$, antibacterial ${ }^{10,11}$, anti-inflammatory ${ }^{11}$, anticonvulsant $^{11,12}$, antitumor activities ${ }^{11,13}$ and other therapeutic agents ${ }^{14,15}$. Due to their wide range of activity and importance, several methods have been developed for the synthesis of $\beta$-enaminones and $\beta$-enamino esters. The most well-known and exploited route toward these compounds involves the direct condensation of $\beta$-dicarbonyl compounds with amines in refluxing aromatic hydrocarbons with azeotropic removal of water ${ }^{16}$. Some improved procedures have been subsequently reported for this transformation using different catalysts such as $\mathrm{P}_{2} \mathrm{O}_{5} / \mathrm{SiO}_{2}{ }^{17}$, clay K-10/uL trasound ${ }^{18}, \mathrm{Zn}\left(\mathrm{ClO}_{4}\right)_{2} \cdot 6 \mathrm{H}_{2} \mathrm{O} / \mathrm{MgSO}_{4}{ }^{19}, \mathrm{NaAuClO}_{4}{ }^{20}$, 
$\mathrm{Bi}(\mathrm{TFA})_{3}{ }^{21}, \mathrm{CeCl}_{3} \cdot 7 \mathrm{H}_{2} \mathrm{O}^{22}, \mathrm{Sc}(\mathrm{OTf})_{3}{ }^{23}, \mathrm{Yb}(\mathrm{OTf})_{3}{ }^{24}$, ionic liquid $\left[\mathrm{EtNH}_{3}\right] \mathrm{NO}_{3}{ }^{25}, \mathrm{HClO}_{4} \cdot \mathrm{SiO}_{2}{ }^{26}$, $\mathrm{ZrOCl}_{2} .8 \mathrm{H}_{2} \mathrm{O}^{27}$, iodine ${ }^{28}$, silica chloride ${ }^{29}$ and $\mathrm{LaCl}_{3} \cdot 7 \mathrm{H}_{2} \mathrm{O}^{30}$. Other synthetic approaches to $\beta$-enaminones include the cyclization of amino acids ${ }^{31}$, reductive cleavage of isoxazoles ${ }^{32}$, condensation of methyl ketones with dimethylformamide dimethylacetal in the presence of equimolar amounts of $[\mathrm{BMIM}] \mathrm{BF}_{4}{ }^{33}$, substitution of the imidoylbenzotriazoles, with trimethylsilyl (TMS) enol ethers ${ }^{34}$ and aminolysis of dithioacetals mediated by copper acetate $^{35}$. However, most of the methods suffer major or minor limitations such as long reaction times, unsatisfactory yields, low selectivity, tedious work-up procedures, lack of general applicability, applications of non-available and costly reagents, the use of hazardous solvents and no agreement with the green chemistry protocols. Moreover, in the case of some of the Lewis acid-catalyzed reactions, no recycling of the catalyst renders these methods environmentally unsound. Thus, searching for a facile, efficient and nonpolluting procedure for the synthesis of $\beta$-enaminones and $\beta$-enamino esters is still of practical importance.

In the aspect of green catalysis has received considerable attention as a stable, inexpensive, non-toxic and readily producible catalyst from available materials for various organic transformations under mild and heterogeneous conditions to afford the corresponding products in excellent yields with high selectivity. Silica sulfuric acid (SSA) is certainly one of these green catalysts that is easily prepared ${ }^{36}$ and has been successfully applied in various organic transformations ${ }^{37}$.

As part of our ongoing program to develop more efficient and environmentally benign methods for organic synthesis using economic and eco-friendly materials as catalysts ${ }^{38-47}$, herein, we report a new, clean and efficient solvent-free method for the synthesis of $\beta$-enaminones and $\beta$-enamino esters from aromatic as well as aliphatic amines and $\beta$-dicarbonyl compounds in the presence of catalytic amount of SSA (Scheme 1). It is important to note that this method has none of the above-mentioned disadvantages at all.

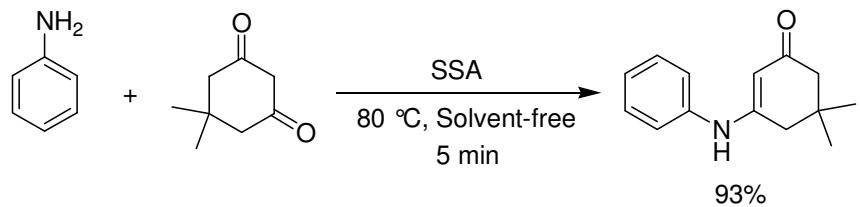

\section{Experimental}

Scheme 1

All chemicals were purchased from Merck or Fluka chemical companies. Silica sulfuric acid was prepared according to the reported procedure ${ }^{36}$. All known compounds were identified by comparison of their melting points and spectral data with those in the authentic samples. The ${ }^{1} \mathrm{H}$ NMR (250 MHz) and ${ }^{13} \mathrm{C}$ NMR $(62.5 \mathrm{MHz})$ were run on a Bruker Avance DPX-250, FT-NMR spectrometer. Microanalysis was performed on a Perkin-Elmer 240-B microanalyzer. Melting points were recorded on a Stuart scientific apparatus SMP3 (UK) in open capillary tubes.

General procedure for the synthesis of $\beta$-enaminone and $\beta$-enamino ester derivatives

To a mixture of amine $(1 \mathrm{mmol})$ and $\beta$-dicarbonyl compound $(1 \mathrm{mmol})$ in a $10 \mathrm{~mL}$ roundbottomed flask connected to a reflux condenser was added SSA $(0.4 \mathrm{~g})$ and the resulting mixture was stirred in an oil-bath $\left(80{ }^{\circ} \mathrm{C}\right)$. After completion of the reaction (monitored by TLC), the reaction mixture was cooled to room temperature and to it was added EtOAc (15 mL), stirred for $5 \mathrm{~min}$ and filtered to separate the catalyst. The solvent of the filtrate was evaporated and the crude product was purified by recrystallization from $\mathrm{EtOH} / \mathrm{H}_{2} \mathrm{O}(1 / 1)$. The recycled catalyst was washed by EtOAc, dried and re-used. 


\section{Selected spectral data of the products}

4-(5,5-Dimethyl-3-oxocyclohex-1-enylamino)phenyl acetate (Table 3, entry 4)

White solid; ${ }^{1} \mathrm{H}$ NMR $\left(\mathrm{CDCl}_{3}\right): \delta 1.13(\mathrm{~s}, 6 \mathrm{H}), 2.10(\mathrm{~s}, 2 \mathrm{H}), 2.24(\mathrm{~s}, 2 \mathrm{H}), 2.76(\mathrm{~s}, 3 \mathrm{H}), 5.73$ $(\mathrm{s}, 1 \mathrm{H}), 7.02(\mathrm{~d}, 2 \mathrm{H}, J=7.1 \mathrm{~Hz}), 7.12(\mathrm{~s}, 1 \mathrm{H}), 7.84(\mathrm{~d}, 2 \mathrm{H}, J=7.1 \mathrm{~Hz}) ;{ }^{13} \mathrm{C} \mathrm{NMR}\left(\mathrm{CDCl}_{3}\right): \delta$ 26.4, 28.1, 32.8, 43.6, 50.3, 100.6, 115.8, 121.2, 140.3, 143.2, 158.8, 196.8, 198.4; Anal. calcd. for $\mathrm{C}_{16} \mathrm{H}_{19} \mathrm{NO}_{3}$ : C, 70.31; H, 7.01; N, 5.12. Found: C, 70.17; H, 6.90; N, 4.98.

\section{3-(4-Bromophenylamino)-5,5-dimethylcyclohex-2-enone (Table 3, entry 5)}

White solid; ${ }^{1} \mathrm{H}$ NMR $\left(\mathrm{CDCl}_{3}\right): \delta 1.02(\mathrm{~s}, 6 \mathrm{H}), 2.14(\mathrm{~s}, 2 \mathrm{H}), 2.36(\mathrm{~s}, 2 \mathrm{H}), 5.13(\mathrm{~s}, 1 \mathrm{H}), 6.66$ (br., $1 \mathrm{H}), 6.96(\mathrm{~d}, 2 \mathrm{H}, J=8.6 \mathrm{~Hz}), 7.39(\mathrm{~d}, 2 \mathrm{H}, J=8.6 \mathrm{~Hz}) ;{ }^{13} \mathrm{C} \mathrm{NMR}\left(\mathrm{CDCl}_{3}\right): \delta 28.5,31.8$, 44.1, 50.4, 100.2, 121.6, 129.8, 132.7, 140.3, 143.2, 198.7; Anal. calcd. for $\mathrm{C}_{14} \mathrm{H}_{16} \mathrm{BrNO}$ : C, 57.16; H, 5.48; N, 4.76. Found: C, 57.29; H, 5.58; N, 4.67.

\section{3-(5,5-Dimethyl-3-oxocyclohex-1-enylamino)benzonitrile (Table 3, entry 6)}

White solid; ${ }^{1} \mathrm{H}$ NMR $\left(\mathrm{CDCl}_{3}\right): \delta 1.16(\mathrm{~s}, 6 \mathrm{H}), 2.16(\mathrm{~s}, 2 \mathrm{H}), 2.42(\mathrm{~s}, 2 \mathrm{H}), 5.60(\mathrm{~s}, 1 \mathrm{H}), 6.66$ (br., $1 \mathrm{H}), 7.19-7.25(\mathrm{~m}, 2 \mathrm{H}), 7.86-791(\mathrm{~m}, 2 \mathrm{H}) ;{ }^{13} \mathrm{C} \mathrm{NMR}\left(\mathrm{CDCl}_{3}\right) \delta: 26.7,32.8,43.4,50.4$, $100.8,106.7,118.6,120.2,121.0,122.1,133.4,143.2,165.1,198.7$; Anal. calcd. for $\mathrm{C}_{15} \mathrm{H}_{16} \mathrm{~N}_{2} \mathrm{O}: \mathrm{C}, 74.97 ; \mathrm{H}, 6.71 ; \mathrm{N}, 11.66$. Found: C, 75.14; H, 6.83; N, 11.74.

\section{5,5-Dimethyl-3-(pyridin-2-ylmethylamino)cyclohex-2-enone (Table 3, entry 8)}

White solid; ${ }^{1} \mathrm{H}$ NMR $\left(\mathrm{CDCl}_{3}\right): \delta 1.14(\mathrm{~s}, 6 \mathrm{H}), 1.92(\mathrm{~s}, 2 \mathrm{H}), 2.19(\mathrm{~s}, 2 \mathrm{H}), 4.35(\mathrm{~s}, 2 \mathrm{H}), 5.20$ (s, 1H), 6.17 (br., $1 \mathrm{H}), 7.22(\mathrm{~m}, 2 \mathrm{H}), 7.68(\mathrm{~m}, 1 \mathrm{H}), 8.55(\mathrm{~m}, 1 \mathrm{H}) ;{ }^{13} \mathrm{C} \mathrm{NMR}\left(\mathrm{CDCl}_{3}\right): \delta 28.3$, $32.9,43.4,46.8,50.3,96.3,122.0,122.7,136.9,148.8,154.6,162.2,196.9$; Anal. calcd. for $\mathrm{C}_{14} \mathrm{H}_{18} \mathrm{~N}_{2} \mathrm{O}: \mathrm{C}, 73.01 ; \mathrm{H}, 7.88 ; \mathrm{N}, 12.16$. Found: C, 72.80; H, 7.96; N, 12.29.

\section{3-(Furan-2-ylmethylamino)-5,5-dimethylcyclohex-2-enone (Table 3, entry 9)}

White solid; ${ }^{1} \mathrm{H}$ NMR $\left(\mathrm{CDCl}_{3}\right): \delta 1.05(\mathrm{~s}, 6 \mathrm{H}), 1.90(\mathrm{~s}, 2 \mathrm{H}), 1.97(\mathrm{~s}, 2 \mathrm{H}), 4.23(\mathrm{~s}, 2 \mathrm{H}), 4.88$ $(\mathrm{s}, 1 \mathrm{H}), 5.06(\mathrm{~s}, 1 \mathrm{H}), 6.25(\mathrm{~d}, 1 \mathrm{H}, J=7.7 \mathrm{~Hz}), 6.31(\mathrm{~m}, 1 \mathrm{H}), 7.34(\mathrm{~d}, 1 \mathrm{H}, J=5.6 \mathrm{~Hz}) ;{ }^{13} \mathrm{C}$ NMR $\left(\mathrm{CDCl}_{3}\right): \delta 27.3,31.5,40.1,43.3,50.2,96.3,107.8,110.5,142.3,149.8 ; 165.6,196.8$; Anal. calcd. for $\mathrm{C}_{13} \mathrm{H}_{17} \mathrm{NO}_{2}$ : C, 71.21; H, 7.81; N, 6.39. Found: C, 71.04; H, 7.70; N, 6.51.

3-(Butylamino)-5,5-dimethylcyclohex-2-enone (Table 3, entry 10)

White solid; ${ }^{1} \mathrm{H}$ NMR $\left(\mathrm{CDCl}_{3}\right): \delta 0.87(\mathrm{t}, J=6.1 \mathrm{~Hz}, 3 \mathrm{H}), 1.06(\mathrm{~s}, 6 \mathrm{H}), 1.31(\mathrm{~m}, 2 \mathrm{H}), 1.51$ $(\mathrm{m}, 2 \mathrm{H}), 2.09(\mathrm{~s}, 2 \mathrm{H}), 2.14(\mathrm{~s}, 2 \mathrm{H}), 3.03(\mathrm{~m}, 2 \mathrm{H}), 4.54(\mathrm{~s}, 1 \mathrm{H}) 5.05(\mathrm{~s}, 1 \mathrm{H}) ;{ }^{13} \mathrm{C} \mathrm{NMR}$ $\left(\mathrm{CDCl}_{3}\right): \delta$ 13.9, 19.8, 27.4, 30.9, 34.1, 40.5, 42.1, 49.9, 96.8, 164.3, 197.0; Anal. calcd. For $\mathrm{C}_{12} \mathrm{H}_{21} \mathrm{NO}$ : C, 73.80; H, 10.84; N, 7.17. Found: C, 73.57; H, 10.68; N, 7.26.

(Z)-4-(3-Oxo-1,3-diphenylprop-1-enylamino)phenyl acetate (Table 3, entry 22)

Pale yellow solid; ${ }^{1} \mathrm{H}$ NMR $\left(\mathrm{CDCl}_{3}\right): \delta 2.49(\mathrm{~s}, 3 \mathrm{H}), 5.28(\mathrm{~s}, 1 \mathrm{H}), 6.77(\mathrm{~d}, J=7.5 \mathrm{~Hz}, 2 \mathrm{H})$, 7.39-7.51 (m, 8H), $7.97(\mathrm{~d}, 2 \mathrm{H}, J=7.5 \mathrm{HZ}), 8.10(\mathrm{~d}, 2 \mathrm{H}, J=7.0 \mathrm{~Hz}), 12.88(\mathrm{~s}, 1 \mathrm{H}) ;{ }^{13} \mathrm{C}$ NMR $\left(\mathrm{CDCl}_{3}\right): \delta 26.1,99.0,113.8,121.6,127.4,128.9,129.3,130.1,130.8,131.8,132.2$, 135.5, 139.4, 144.1, 160.0, 190.3, 196.8; Anal. calcd. for $\mathrm{C}_{23} \mathrm{H}_{19} \mathrm{NO}_{3}: \mathrm{C}, 77.29 ; \mathrm{H}, 5.36 ; \mathrm{N}$, 3.92. Found: C, $77.11 ; \mathrm{H}, 5.49 ; \mathrm{N}, 4.01$.

\section{Results and Discussion}

At first, the reaction of aniline $(1 \mathrm{mmol})$ with dimedone $(1 \mathrm{mmol})$ was examined in the presence of different amounts of SSA at range of $25-90{ }^{\circ} \mathrm{C}$ under solvent-free conditions in order to optimize the reaction conditions with respect to amount of the catalyst and 
temperature (Scheme 1). The results are summarized in Table 1. As it can be seen from Table 1, the reasonable results were obtained when the reaction was carried out using $0.4 \mathrm{~g}$ SSA at $80^{\circ} \mathrm{C}$.

Table 1. Effect of amount of SSA and temperature on the reaction of aniline with dimedone

\begin{tabular}{cccc}
\hline Amount of SSA, $\mathrm{g}$ & Temperature, ${ }^{\circ} \mathrm{C}$ & Time, min & Yield $^{\mathrm{a}}, \%$ \\
\hline 0.1 & 80 & 50 & 67 \\
0.2 & 80 & 30 & 79 \\
0.3 & 80 & 10 & 88 \\
0.4 & 80 & 5 & 93 \\
0.5 & 80 & 5 & 93 \\
0.4 & 25 (r.t.) & 120 & Trace \\
0.4 & 60 & 20 & 71 \\
0.4 & 70 & 10 & 87 \\
0.4 & 90 & 4 & 91 \\
\hline \multicolumn{4}{c}{ Isolated yield. }
\end{tabular}

In another study, the reaction was checked in several solvents to recognize the efficiency of the solvent-free procedure in comparison to solution conditions. For this purpose, a mixture of aniline $(1 \mathrm{mmol})$, dimedone $(1 \mathrm{mmol})$ and SSA $(0.4 \mathrm{~g})$ was stirred in different solvents $(10 \mathrm{~mL})$ at 80 or under reflux conditions (Table 2). As Table 2 indicates, the solvent-free method afforded the product in higher yield and shorter reaction time.

Table 2. Comparative the reaction between aniline and dimedone using SSA in solution conditions versus the solvent-free method

\begin{tabular}{cccc}
\hline Solvent & Temperature, ${ }^{\circ} \mathrm{C}$ & Time, min & Yield $^{\text {a }}, \%$ \\
\hline $\mathrm{H}_{2} \mathrm{O}$ & 80 & 60 & 27 \\
$\mathrm{EtOH}$ & Reflux & 60 & 76 \\
$\mathrm{MeOH}$ & Reflux & 60 & 69 \\
$\mathrm{CHCl}_{3}$ & Reflux & 60 & 66 \\
$\mathrm{CH}_{3} \mathrm{CN}$ & Reflux & 60 & 58 \\
$\mathrm{THF}$ & Reflux & 60 & 45 \\
Solvent-free & 80 & 5 & 93 \\
\hline \multicolumn{4}{c}{}
\end{tabular}

To assess the generality and scope of our method, different aromatic and aliphatic amines were reacted with some $\beta$-diketones and $\beta$-ketoesters. The results are displayed in Table 3 . As it is shown in Table 3, all reactions proceeded efficiently and the desired products were obtained in high to excellent yields and in short reaction times. The results showed that the presence of electron-releasing substituents or halogens on the aromatic ring of aromatic amines had no significant effect on the reaction results (Table 3, entries 2-5, 12-14, 22 and 26-29); however, electron-withdrawing substituents slightly decreased the yields (Table 3, entry 6). The condensation of aliphatic amines, $\mathrm{NH}_{4} \mathrm{OAc}$ as well as diamines with $\beta$-dicarbonyl compounds was also successfully carried out and the corresponding products were obtained in high to excellent yields and short reaction times (Table 3, entries 7-10, 15-17, 19, 20, 23 and 30-32). 
Table 3. Synthesis of $\beta$-enaminones and $\beta$-enamino esters using SSA under solvent-free conditions at $80{ }^{\circ} \mathrm{C}$

\begin{tabular}{|c|c|c|c|c|}
\hline Entry & Product & $\begin{array}{c}\text { Time, } \\
\text { min }\end{array}$ & $\begin{array}{c}\text { Yield }^{\mathrm{a}}, \\
\%\end{array}$ & M.p. ${ }^{\circ} \mathrm{C}$ (Lit.) \\
\hline 1 & & 5 & 93 & $184-186(185)^{48}$ \\
\hline 2 & & 8 & 86 & $126-128(129-131)^{49}$ \\
\hline 3 & & 3 & 96 & $192-194(195)^{48}$ \\
\hline 4 & & 7 & 92 & $226-228(225-227)^{17}$ \\
\hline 5 & & 7 & 93 & $219-220(219-220)^{17}$ \\
\hline 6 & & 5 & 87 & $181-183$ \\
\hline 7 & & 5 & 95 & $127-128(125)^{48}$ \\
\hline 8 & & 6 & 94 & $160-161(162-163)^{17}$ \\
\hline 9 & & 6 & 95 & $148-150$ \\
\hline 10 & & 8 & 92 & $117-119$ \\
\hline
\end{tabular}




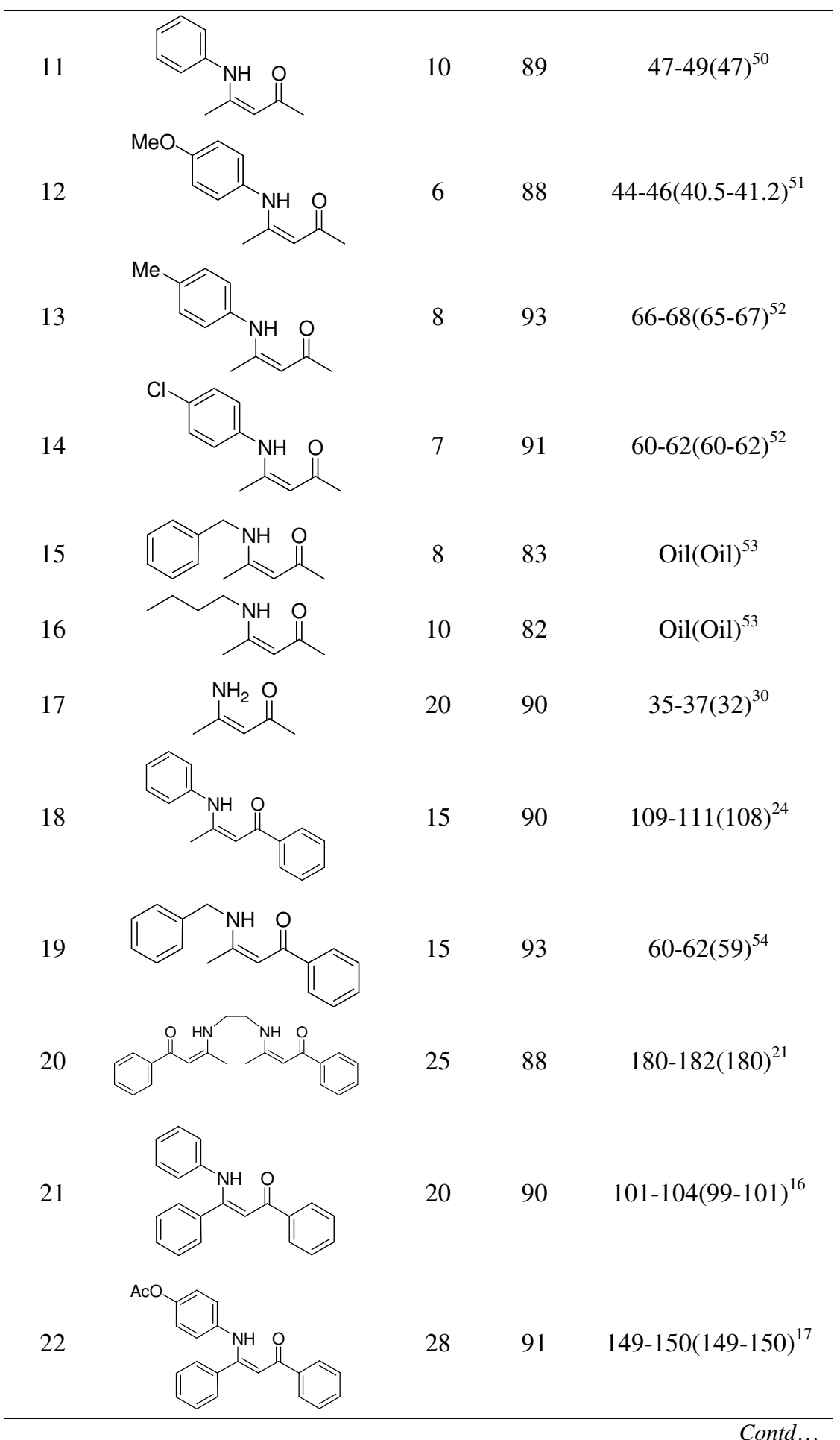




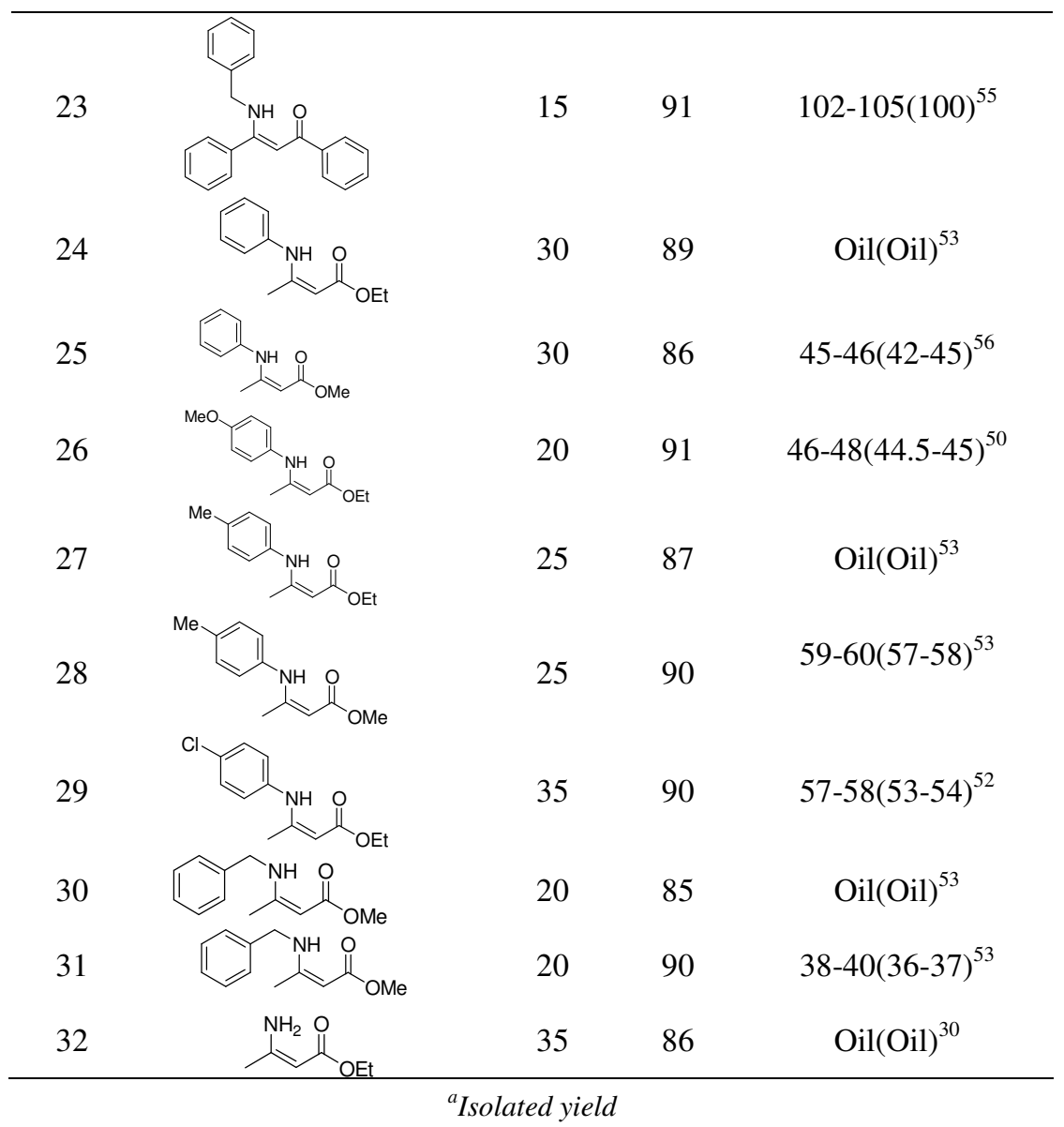

The interesting behavior of SSA lies in the fact that it can be reused after simple washing with EtOAc, thus rendering process more economical. For the reaction of aniline with dimedone no significant loss of the product yield was observed when the catalyst was reused after three times recycling (Table 4).

Table 4. The condensation of aniline with dimedone in the presence of recycled SSA

\begin{tabular}{cccc}
\hline Entry & Cycle & Time, min & Yield $^{\text {a }} \%$ \\
\hline 1 & $1^{\text {st }}$ use & 5 & 93 \\
2 & $2^{\text {nd }}$ use & 5 & 93 \\
3 & $3^{\text {rd }}$ use & 10 & 92 \\
4 & $4^{\text {th }}$ use & 25 & 87 \\
5 & $5^{\text {th }}$ use & 30 & 79 \\
\hline
\end{tabular}

\section{Conclusion}

In summary, we have developed a new efficient method for the synthesis of $\beta$-enaminones and $\beta$-enamino esters from amines and $\beta$-dicarbonyl compounds. The advantages the presented methodology are efficiency, generality, high yield, short reaction time, low cost, cleaner reaction profile, ease of product isolation, simplicity, potential for recycling of the catalyst and finally agreement with the green chemistry protocols. 


\section{Acknowledgment}

The authors thank Persian Gulf University and Payame Noor University Research Councils for the financial support of this work.

\section{References}

1. Rappoport Z (Eds), The Chemistry of Enamines, John Wiley \& Sons, New York, 1994, Part 1, pp 525-639.

2. Vohra R K, Renaud J L and Bruneau C, Collect Czech Chem Commun., 2005, 70, 1943.

3. Stevens C V, Kesteleyn B, Alonso E R and De Kimpe N, Tetrahedron, 2001, 57, 7685.

4. Elassar A Z A and El-Khair A A, Tetrahedron, 2003, 59, 8463.

5. Alan C, Spivey A C, Srikaran R, Diaper C M, David J and Turner D, Org Biomol Chem., 2003, 1638 and the references cited therein.

6. Michael J P, De Koning C B, Gravestock D, Hosken G D, Howard A S, Jungmann C M, Krause R W M, Parsons A S, Pelly S C and Stanbury T V, Pure Appl Chem., 1999, 71, 979-988.

7. Hassneen H M and Abdallah T A, Molecules, 2003, 8, 333.

8. Edafiogho I O, Ananthalakshmi K V V and Kombian S B, Bioorg Med Chem., 2006, 14, 5266.

9. Khurana M, Salama N N, Scott K R, Nemieboka N N, Jr Bauer K S and Eddington N D, Drug Dispos, 2003, 24, 397.

10. Wang Y F, Izawa T, Kobayashi S and Ohno M, J Am Chem Soc., 1982, 104, 6465.

11. Michael J P, Koning C B, Hosken G D and Stanbury T V, Tetrahedron, 2001, 57, 9635.

12. Edafiogho I O, Alexander M S, Moore J A, Farrar V A and Scott KR, Curr Med Chem., 1994, 1, 159-175.

13. Boger D L, Ishizaki T, Jr Wysocki J R, Munk S A, Kitos P A and Suntornwat O, J Am Chem Soc., 1989, 111, 6461.

14. White J D and Ihle D C, Org Lett., 2006, 8, 1081.

15. Edafiogho I O, Kombian S B, Ananthalakshmi K Y V V, Salama N N, Eddington N D, Wilson T L, Alexander M S, Jackson P L, Hanson C D and Scott K R, J Pharm Sci., 2007, 96, 2509.

16. Martin D F, Janusonis G A and Martin B B, J Am Chem Soc., 1961, 83, 73.

17. Mohammadizadeh M R, Hasaninejad A, Bahramzadeh M and Khanjarloo Z S, Synth Commun., 2009, 39, 1152.

18. Valduga C J, Squizani A, Braibante H S and Braibante M E F, Synthesis, 1998, 1019.

19. Bartoli G, Bosco M, Locatelli M, Marcantoni E, Melchiorre P and Sambri L, Synlett, 2004, 239.

20. Arcadi A, Bianchi G, Giuseppe S D and Marinelli F, Green Chem., 2003, 5, 64-67.

21. Khosropour A R, Khodaei M M and Kookhazadeh M, Tetrahedron Lett., 2004, 45, 1725.

22. Khodaei M M, Khosropour A R and Kookhazadeh M, Synlett, 2004, 1980.

23. Yadav J S, Kumar V N, Rao R S, Priyadarshini A D, Rao P P, Reddy B V S and Nagaiah K, J Mol Catal A: Chem., 2006, 256, 234.

24. Epifano F, Genovese S and Curini M, Tetrahedron Lett., 2007, 48, 2717.

25. Bhosale R S, Suryawanshi P A, Ingle S A, Lokhande M N, More S P, Mane S B, Bhosale S V and Pawar R P, Synlett, 2006, 933.

26. Das B, Venkateswarlu K, Majhi A, Reddy M R, Reddy K N, Rao Y K, Ravikumar K and Srihar B, J Mol Catal A: Chem., 2006, 246, 276.

27. Zhang Z H, Li T-S and Li J J, Catal Commun., 2007, 8, 1615. 
28. Gogoi S, Bhuyan R and Barua N C, Synth Commun., 2005, 35, 2811.

29. Gholap A R, Chakor N S, Daniel T, Lahoti R J and Srinivasan K V, J Mol Catal A: Chem., 2006, 245, 37.

30. Lenin R and Raju R M, ARKIVOC, 2007, xiii, 204.

31. Turunen B J and Georg G I, J Am Chem Soc., 2006, 128, 8702.

32. Calle M, Calvo L A, Gonzales-Ortega A and Gonzales-Nogal A, Tetrahedron, 2006, 62, 611 .

33. Martins M A P, Frizzo C P, Moreira D N, Rosa F A, Marzari M R B, Zanatta N and Bonacorso H G, Catal Commun., 2007, 9, 375.

34. Katritzky A R, Hayden A E, Kirichenko K, Pelphrey P and Ji Y, J Org Chem., 2004, 69, 5108.

35. Kang J, Liang F, Sun S-G, Liu Q and Bi X-H, Org Lett., 2006, 8, 2547.

36. Zolfigol M A, Tetrahedron, 2001, 57, 9509.

37. Salehi P, Zolfigol M A, Shirini F and Baghbanzadeh M, Curr Org Chem., 2006, 10, 2171 (Review).

38. Hasaninejad A, Zare A, Shekouhy M, Moosavi-Zare A R, E-J Chem., 2009, 6(S1), S247.

39. Zare A, Hasaninejad A, Rostami E, Moosavi-Zare A R, Merajoddin M, Arghoon A, Pishahang N and Shekouhy M, E-J Chem.,2009, 6(S1), S390.

40. Hasaninejad A, Zare A, Jafari F and Moosavi-Zare A R, E J Chem. 2009, 6, 459.

41. Hasaninejad A, Zare A, Zolfigol M A and Shekouhy M, Synth Commun., 2009, 39, 569-579.

42. Zare A, Parhami A, Moosavi-Zare A R, Hasaninejad A, Khalafi-Nezhad A and Beyzavi M H, Can J Chem., 2009, 87, 416.

43. Zare A, Hasaninejad A, Beyzavi M H, Moosavi Zare A R, Khalafi-Nezhad A, Asadi F, Baramaki L, Jomhori-Angali S and Ghaleh-Golabi R, Synth Commun., 2009, 39, 139.

44. Khalafi-Nezhad A, Parhami A, Zare A, Moosavi Zare A R, Hasaninejad A and Panahi F, Synthesis, 2008, 617.

45. Zare A, Hasaninejad A, Beyzavi M H, Parhami A, Moosavi Zare A R, KhalafiNezhad A and Sharghi H, Can J Chem., 2008, 86, 317.

46. Zare A, Hasaninejad A, Khalafi-Nezhad A, Parhami A and Moosavi Zare A R, J Iran Chem Soc., 2008, 5, 100.

47. Zare A, Hasaninejad A, Shekouhy M and Moosavi Zare A R, Org Prep Proced Int., 2008, 40, 457.

48. Scott K R, Edafiogho I O, Richardson E L, Farrar V A, Moore J A, Tietz E I, Hinko C N, Chang H, El-Assadi A and Nicholson J M, J Med Chem., 1993, 36, 1947.

49. Iida H, Yuasa Y and Kibayashi C, J Org Chem., 1980, 45, 2938.

50. Werner W, Tetrahedron, 1971, 27, 1755.

51. Zhou J C, Magn Reson Chem., 1997, 35, 311.

52. Potesil T, J Chromatogr., 1984, 312, 387.

53. Zhang Z-H, Yin L and Wang Y-M, Adv Synth Catal., 2006, 348, 184.

54. Kibayashi C, Yuasa Y and Lida H, J Chem Soc Dalton Trans., 1981, 11, 2212.

55. Coromwell N H, Chem Rev., 1946, 38, 83.

56. Yale H L and Spitzmiller E R, J Heterocycl Chem., 1977, 14, 1419. 


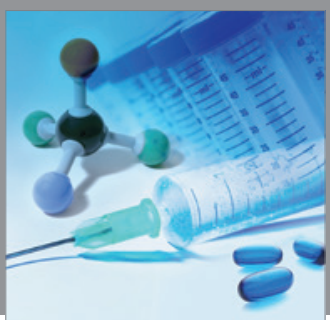

International Journal of

Medicinal Chemistry

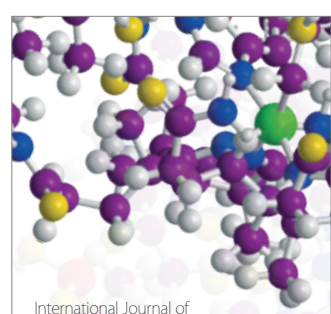

Carbohydrate Chemistry

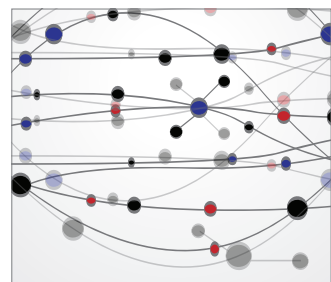

The Scientific World Journal
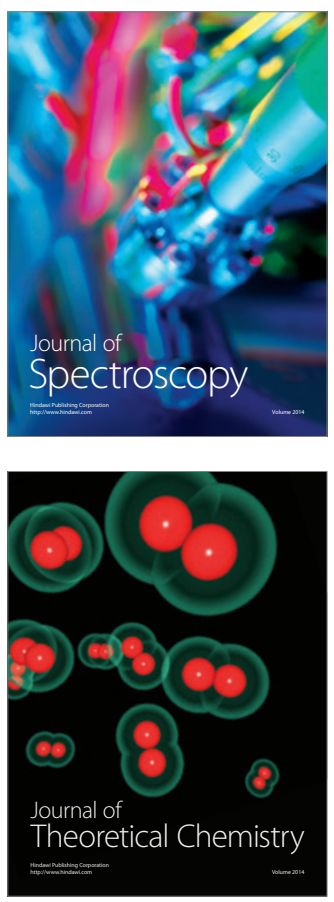
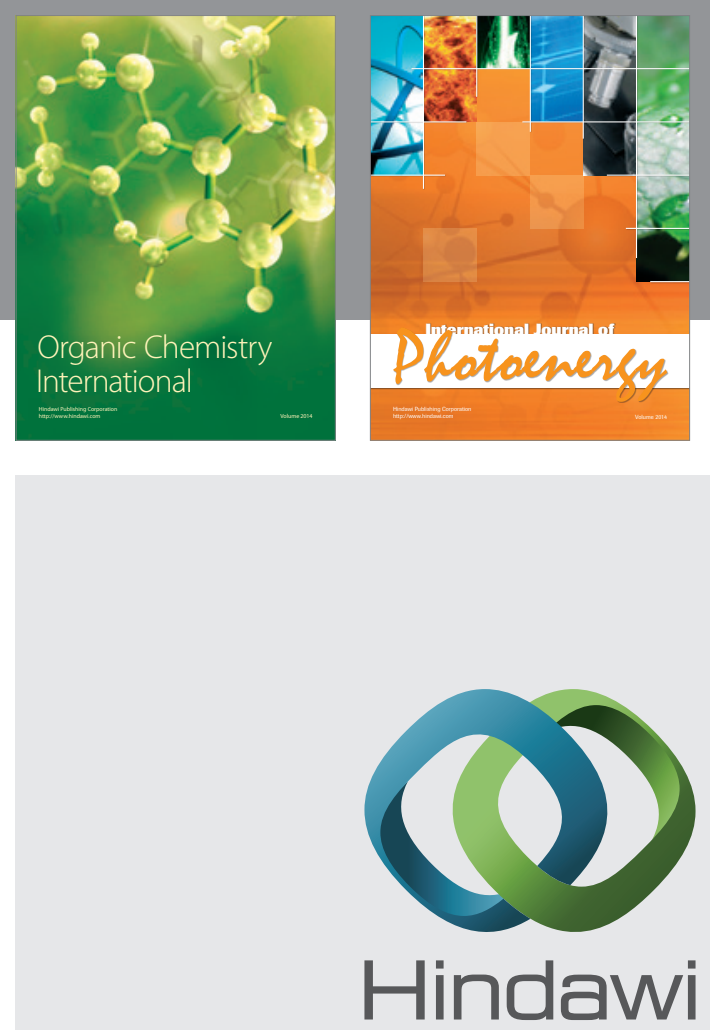

Submit your manuscripts at

http://www.hindawi.com
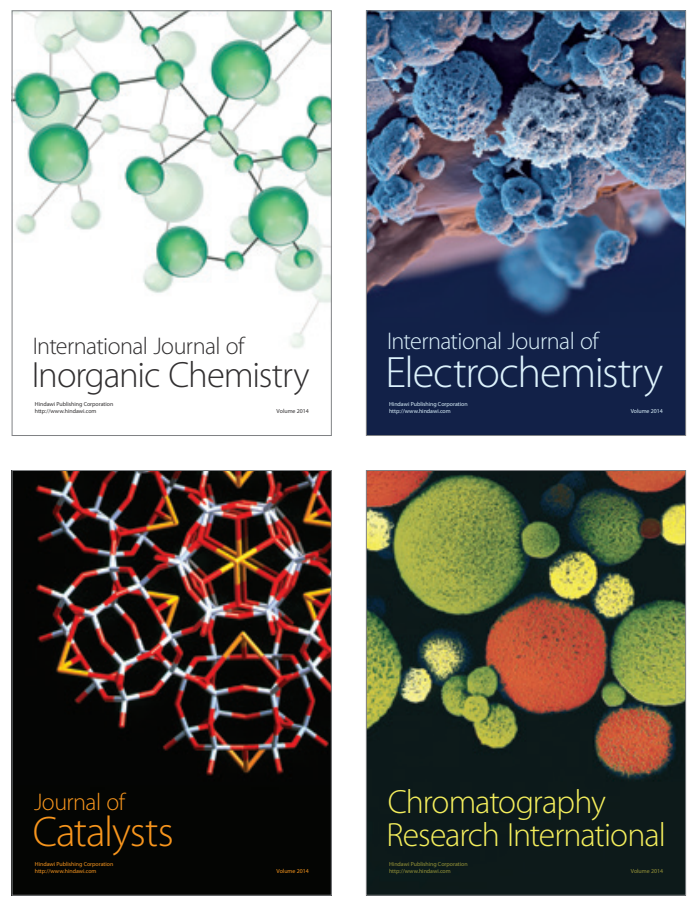
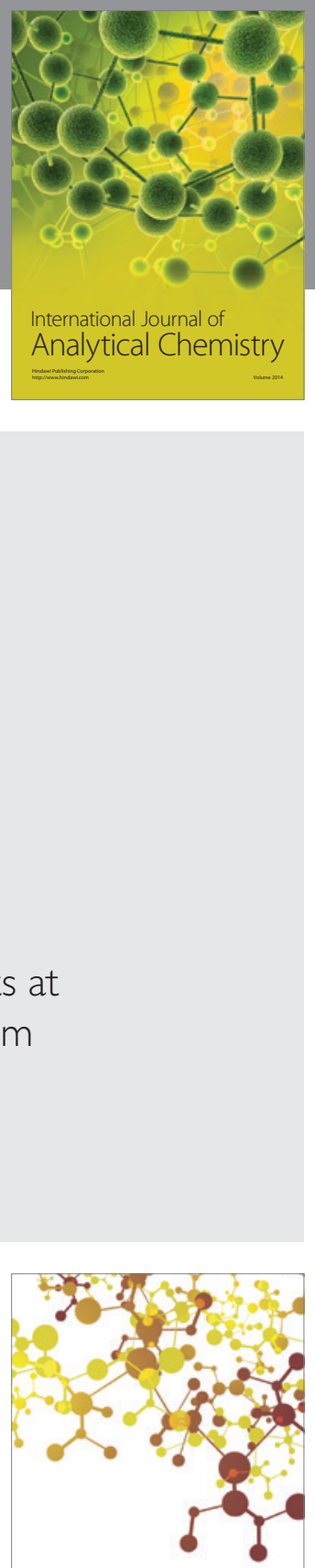

Journal of

Applied Chemistry
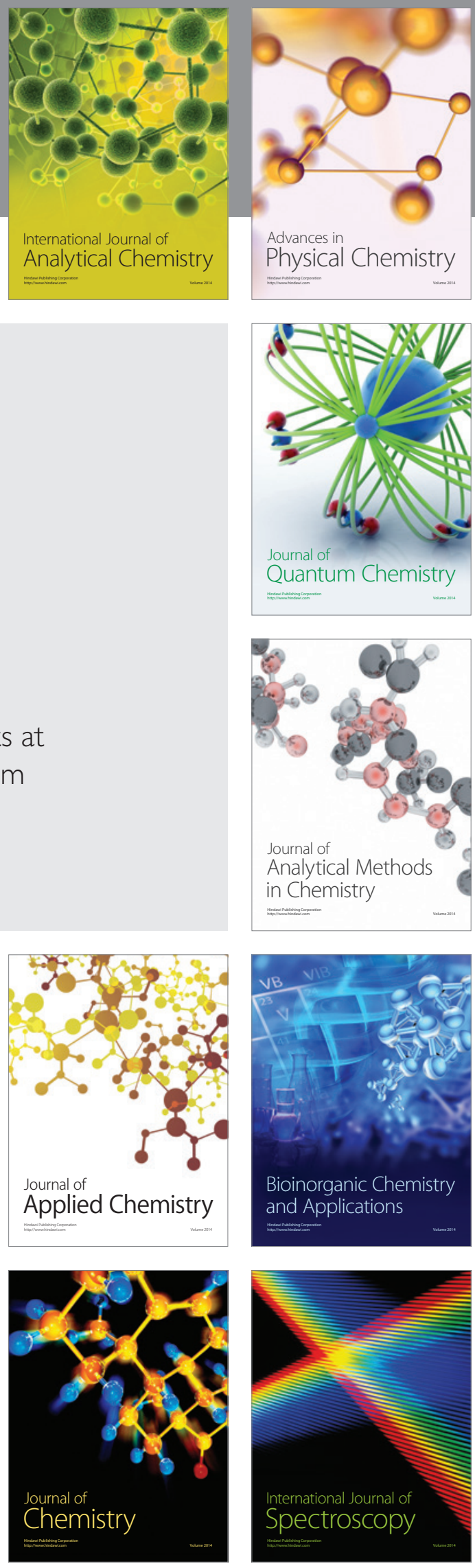